\title{
ANALISIS KESALAHAN PENGGUNAAN PARTIKEL NI DAN DE
}

\author{
Elisa Carolina Marion
}

Japanese Department, Faculty of Literature, Bina Nusantara University, Jl. Kemanggisan Ilir III No. 45, Kemanggisan/Palmerah, Jakarta Barat 11480, emarion@binus.edu

\begin{abstract}
Articel clasified the type and cause of mistake done by Bina Nusantara Japanese student of six and eight semesters on the use of ni (に) and de (で) particles indicating place in the exam. Data were collected from library research and distributed questionnaires to 79 student of the $6^{\text {th }}$ and $8^{\text {th }}$ semester, Japanese departement. The result showed that the student of Japanese language did not make the same mistake in using the $\mathrm{ni}$ (に) and de (で) particles having the some function in indicating place. It is concluded that the respondents are able to use the ni (に) and de (で) particles.
\end{abstract}

Keywords: mistake analysis, ni particle, de particle

\begin{abstract}
ABSTRAK
Artikel bertujuan untuk mengetahui jenis dan penyebab kesalahan yang dilakukan mahasiswa semester enam dan delapan jurusan bahasa Jepang, Universitas Bina Nusantara, Jakarta terhadap soal bahasa Jepang tingkat dasar, yaitu pemakaian partikel ni (に) dan de (で) yang berfungsi menunjukkan tempat/keberadaan. Data diperoleh dari studi pustaka dan penyebaran kuisioner ke 79 responden, yaitu mahasiswa jurusan sastra Jepang semester enam dan delapan. Hasil yang dicapai adalah mahasiswa pemelajar Bahasa Jepang tidak lagi melakukan kesalahan yang sama dalam membedakan penggunaan partikel ni (に) dan de (で) yang sama-sama berfungsi menunjukkan tempat/keberadaan. Simpulan yang dapat ditarik adalah secara umum responden menguasai pemakaian partikel ni (に) dan de (で) yang berfungsi menunjukkan tempat/keberadaan.
\end{abstract}

Kata kunci: analisis kesalahan, partikel ni, partikel de 


\section{PENDAHULUAN}

Dalam penggunaan bahasa Jepang, baik secara lisan maupun tulisan tidak pernah lepas dari partikel atau yang dikenal dengan istilah Joshi(助詞). Menurut Kamus Lingustik Edisi Ketiga, partikel adalah kata yang biasanya tidak dapat diderivasikan atau diinfleksikan yang mengandung makna gramatikal dan tidak mengandung makna leksikal, misalnya preposisi seperti di, dari, konjungsi seperti dan, atau, dan sebagainya (Harimurti Kridalaksana, 1993:155). Menurut Sugihartono (2001:viii) dalam bukunya yang berjudul Nihongo No Joshi(日本語の助詞), partikel didefinisikan sebagai berikut: “Joshi (助詞) adalah jenis kata yang tidak mengalami perubahan, dan tidak bisa berdiri sendiri yang memiliki fungsi membantu, dan menentukan: arti, hubungan, penekanan, pertanyaan, keraguan, dan lainnya dalam suatu kalimat Bahasa Jepang, baik dalam ragam lisan maupun ragam tulisan."

Dalam tata bahasa Jepang, fungsi partikel menduduki posisi yang sangat penting. Jumlah partikel dalam bahasa Jepang cukup banyak sehingga menjadi keunikan dan kekhasan tersendiri bagi bahasa Jepang. Rumitnya, satu partikel dalam bahasa Jepang memiliki fungsi lebih dari satu. Dan tentu saja dengan beragamnya fungsi partikel itu semakin menambah kompleksitas pemahaman bahasa Jepang.

Di dalam keragaman partikel bahasa Jepang juga terdapat pasangan partikel yang cukup membingungkan bagi pemelajar bahasa Jepang dalam menggunakannya. Seperti pasangan partikel $w a$ dan $g a$ (ハとガ)atau partikel $n i$ dan $d e$ (ニとデ). Pasangan partikel tersebut memiliki kemiripan arti atau fungsi yang membingungkan pemelajar bahasa Jepang dalam membedakan penggunaannya.

\section{PEMBAHASAN}

\section{Teori Pemakaian Partikel $\mathrm{Ni}($ に) dan De( で ) yang Menunjukkan "Tempat/Keberadaan"}

Partikel $n i$ dan de memiliki berbagai macam fungsi dan penggunaan. Diantara berbagai macam fungsi dan penggunaan kedua partikel tersebut, ada salah satu fungsi yang dimiliki oleh keduanya, yakni fungsi yang menunjukkan tempat/keberadaan. Meskipun demikian, hal itu bukan berarti bahwa aturan penggunaannya serupa. Ada beberapa perbedaan dalam penggunaannya yang selama ini belum begitu dikuasai oleh para pemelajar bahasa Jepang. Berikut merupakan teori penggunaan partikel $n i($ に) dan $d e$ (で) yang menunjukkan tempat keberadaan menurut Masuoka dan Takubo (2000).

1. 物や人が存在する位置を示す場合には二を使う。

Partikel ni digunakan untuk menunjukkan keberadaan benda atau orang.

Pola kalimat:

$$
\text { (場所) ニ+ (主体) ガ+ 動詞 }
$$


Contoh:

a. 電話機のそばニテレビガある。

Di sebelah televisi ada telepon.

b. この近くニスーパーガできるらしい。

Kalau tidak salah di dekat sini ada supermarket.

(Masuoka dan Takubo, 2000:52)

$$
\text { (主体) ガ/ハ + (場所 }) \text { ニ 動詞 }
$$

(Subjek) $g a / w a+($ Keterangan tempat) $n i+$ Kata Kerja

Contoh:

わたしはは㕫きょう

a. 私の母八東京二いる。

Ibu saya sedang ada di Toukyou.

b. 電車八東京駅二止まった。

Kereta berhenti di stasiun Toukyou.

(Masuoka dan Takubo, 2000:52)

2. 動作が行われたり、出来事が起こる場所はデで表す。

Partikel de digunakan untuk menunjukkan tempat terjadinya suatu peristiwa/kejadian atau gerakan.

Pola kalimat:

(主体) ガ/ハ + (場所 $)$ デ + (裏作 $)$

(Subjek) $g a / w a+($ Keterangan Tempat $) d e+($ Kata Kerja $)$

Contoh:

a. 私 八これから部屋デ本を読む。(Masuoka dan Takubo, 2000:52)

Saya sekarang akan membaca buku di kamar.

b. 昨日母ハモモールデ新しいめが称を筫いました。

Kemarin ibu membeli kacamata baru di mall.

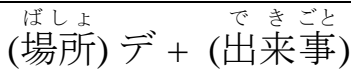

(Keterangan Tempat) $D e+($ Peristiwa/Kejadian)

Contoh:

3時に 10 号室デ会議がある。

Ada rapat jam 3 di ruang nomor 10 .

(Masuoka dan Takubo, 2000:52)

Catatan:

Meskipun dalam contoh kalimat di atas menggunakan kata kerja aru (ある), tidak boleh menggunakan partikel $n i(に)$ karena pada kalimat tersebut menunjukkan adanya suatu peristiwa atau kegiatan. 
3. 状涗が成立する場所はデ (八)で表す。

Partikel de digunakan untuk menunjukkan tempat yang membentuk suatu keadaan.

Pola kalimat:

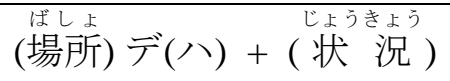

(Keterangan tempat) de $(w a)+($ Keterangan keadaan $)$

Contoh:
a. 日本デは、握手はあまり一般的ではありません。
Di Jepang, berjabat tangan tidak begitu biasa.
b. 年本二は、握手の習慣はありません。
Di Jepang tidak ada kebiasaan berjabat tangan.
(Masuoka dan Takubo, 2000:53)

Catatan:

Contoh kalimat a menunjukkan suatu keadaan (keadaan berjabat tangan) sedangkan pada contoh kalimat b menunjukkan suatu keberadaan (keberadaan dari kebiasaan berjabat tangan). Dengan demikian, pada contoh kalimat a digunakan partikel de dan pada contoh kalimat $\mathrm{b}$ digunakan partikel ni.

4. 2番の (動作) の部分に位置の二が含まれる時は、当然デと二を組み合わせてもよい。 Pada saat partikel $n i$ yang menunjukkan keberadaan dimasukkan ke dalam bagian dari suatu gerakan, dengan sendirinya kalimat terbebut menggunakan kombinasi antara partikel $n i$ dan $d e$.

Contoh:
a. 花子は神戸で高 級マンションに住んでいます。
Hanako tinggal di apartemen mewah di Koube.
b. 太郎は神戸で貿易会社に勤めている。

Tarou bekerja di perusahaan perdagangan luar negeri di Koube.

(Masuoka dan Takubo, 2000:53)

5. デは、動詞の種類と関係なく使うことができるのに対し、ニは、位置のニを補語とし て要求する動詞とともにしか使えない。

位置の二を茸らない動詞: 「読む、話す、働く、食べる、飲む、聞く、遊ぶ、研究す る」など、多くの動作動詞。

Partikel de dapat digunakan dengan kata kerja manapun tanpa memperhatikan jenis dari kata kerja tersebut sedangkan partikel $n i$ hanya dapat digunakan dengan kata kerja yang meminta partikel $n i$ sebagai pelengkap dari keberadaan.

Kata kerja yang tidak menggunakan partikel $n i$ untuk menunjukkan tempat keberadaan adalah membaca, berbicara, bekerja, makan, minum, mendengar, bermain, menyelidiki, dan kata kerja lainnya yang mengandung unsur pergerakan.

Contoh:
a. 彼は部屋(*ニ/デ)本を読んでいる。

Dia sedang membaca buku di kamar. 
b. 太郎は東京 (*ニ/デ) 働いている。

Tarou sedang bekerja di Toukyou.

(Masuoka dan Takubo, 2000:53)

位置の二を取る動詞:「いる、座る、泊まる、立つ、滞在する、住む、留まる、止まる、 勤める」など。

Kata kerja yang menggunakan partikel $n i$ untuk menunjukkan tempat keberadaan adalah: ada, duduk, menginap, berdiri, menginap, tinggal, berhenti, bekerja, dan lain-lain.

Contoh:

a. 彼は部屋の隅二座つていた。

Dia tadi duduk di sudut kamar.

b. 私は東京二住みたい。

Saya ingin tinggal di Jepang.

(Masuoka dan Takubo, 2000:53)

\section{Teori Analisis Kesalahan Berbahasa}

Analisis kesalahan berbahasa menurut Parera (1997:98) merupakan satu tindakan dan studi secara formal dan sistematik untuk mengidentifikasikan kesulitan, hambatan, dan kendala dalam proses pembelajaran bahasa bagi mereka yang berbeda latar belakang kebahasaan. Melalui analisis kesalahan berbahasa, dapat diungkap berbagai hal mengenai kesalahan berbahasa yang dibuat oleh para pemelajar bahasa, yaitu latar belakang, sebab kesalahan, dan ragam kesalahan. Tujuan analisis kesalahan berbahasa adalah meningkatkan dan memperbesar keberhasilan pembelajaran dan pengajaran berbahasa.

Prosedur kerja dalam analisis kesalahan berbahasa menempuh langkah sebagai berikut (Parera, 1997). Pertama, pengumpulan data. Pengumpulan data dilakukan dengan membagikan kuisioner yang berisi soal mengenai partikel $n i$ (に) dan de (で) kepada 79 orang mahasiswa semester enam dan delapan Jurusan Bahasa Jepang Fakultas Sastra Universitas Bina Nusantara. Kuesioner yang dibagikan telah melalui proses validasi berdasarkan teori validasi isi (fernandez, 1984) dan dinyatakan valid karena kuesioner berisi soal seputar penggunaan partikel $n i($ に) dan $d e(て ゙)$ yang sesuai dengan kualifikasi mahasiswa semester 6 (enam) dan 8 (delapan), yaitu dimiliki mahasiswa pada tingkat menengah adalah pengetahuan kosakata antara 5000 dan 7000 kata, 1000, dan 1500 kanji. Kemudian kemampuan melakukan percakapan sehari-hari serta mampu membaca dan menulis kalimat yang sesuai dengan gramatika tingkat menengah (Nihongo Kyoiku Jiten, 1982:633-635 dalam Herniwati, 2001:13). Selain itu, kuesioner ke-2 berisi beberapa pertanyaan mendasar mengenai latar belakang mahasiswa yang mendukung penelitian. Beberapa pertanyaan mengenai latar belakang mahasiswa dibutuhkan untuk membantu penulis dalam mengidentifikasikan penyebab kesalahan yang dilakukan mahasiswa pemelajar bahasa Jepang.

Kedua, pengidentifikasian kesalahan. Pengidentifikasian kesalahan dilakukan dengan menyesuaikan jawaban dengan teori mengenai perbedaan partikel $n i$ (に) dan de (で) yang dipakai dalam penelitian ini. Hasil penelitian yang didapat telah diuji melalui teori reliabilitas dengan pertimbangan: Kuesioner dibagikan kepada mahasiswa pemelajar Bahasa Jepang tingkat menengah, yaitu mahasiswa semester 6 dan 8; Kuesioner dibagikan kepada mahasiswa pemelajar Bahasa Jepang yang sudah menguasai pengetahuan kosakata antara 5000 dan 7000 kata, 1000, dan 1500 kanji kemudian kemampuan melakukan percakapan sehari-hari serta mampu membaca dan menulis kalimat 
yang sesuai dengan gramatika tingkat menengah (Nihongo Kyoiku Jiten, 1982:633-635 dalam Herniwati, 2001:13); Kuesioner dibagikan kepada mahasiswa pemelajar bahasa Jepang yang sudah mempelajari partikel $n i$ (に) dan de (で).

Ketiga, mengklasifikasikan kesalahan. Pengklasifikasian kesalahan dilakukan dengan mengelompokkan kesalahan berdasarkan jenis kesalahan yang dilakukan oleh mahasiswa pemelajar Bahasa Jepang. Keempat, menjelaskan frekuensi kesalahan. Menjelaskan frekuensi kesalahan dilakukan dengan menghitung total frekuensi kesalahan yang dilakukan mahasiswa pada tiap soal. Kelima, mengidentifikasikan daerah kesukaran/kesalahan. Mengidentifikasikan daerah kesukaran dilakukan dengan menganalisis hubungan antara kesalahan yang dibuat oleh pemelajar bahasa sasaran dengan bahasa pertama. Keenam, mengoreksi kesalahan. Pengoreksian kesalahan dilakukan dengan cara menyesuaikan jawaban yang salah dengan teori yang dipakai dalam penelitian.

Kesalahan berbahasa muncul karena adanya perbedaan antara sistem bahasa pertama atau bahasa ibu (B1) pembelajar dengan sistem bahasa kedua atau bahasa target atau bahasa asing (B2) yang dipelajari. Dalam hal pengajaran bahasa, Corder (dalam dari Parera, 1997:143) membedakan dua macam kesalahan, yaitu mistake dan error. Mistake merupakan penyimpangan yang tidak sistematis yang disebabkan oleh faktor perfomance, seperti keterbatasan dalam mengingat, kelelahan, emosi, atau salah ucap. Kesalahan seperti itu mudah diperbaiki oleh pemelajar sendiri bila yang bersangkutan mawas diri, lebih sadar, atau memusatkan perhatian. Error merupakan penyimpangan yang sistematis dan konsisten dan menggambarkan kemampuan pemelajar pada tahap tertentu. Kesalahan yang seperti itu terjadi karena pemelajar belum memahami sistem linguistik bahasa yang sedang digunakannya. Bila tahap pemahaman pemelajar akan sistem bahasa yang sedang dipelajarinya kurang maka kesalahan akan sering terjadi. Dan kesalahan akan berkurang apabila tingkat pemahaman pemelajar terhadap sistem bahasa yang sedang dipelajarinya semakin meningkat. Kesalahan dapat berlangsung lama jika tidak diperbaiki dan perbaikan biasanya dilakukan oleh guru.

Sumber utama penyebab kesalahan bahasa yang dilakukan pemelajar, terutama pemelajar yang sedang belajar bahasa asing atau bahasa kedua menurut Brown (1980:172-181) dikutip dari Herniwati (2001:18) dan Jack Richard (dikutip dari Parera, 1997:138-139) adalah sebagai berikut. Pertama, Transfer Interlingual. Kesalahan karena transfer interlingual disebabkan pengaruh atau penggunaan unsur atau kaidah bahasa ibu pada bahasa target. Pengaruh bahasa ibu pada bahasa target yang sedang dipelajari merupakan hal yang sering terjadi pada tahap permulaan pembelajaran bahasa target atau bahasa kedua. Kedua, Transfer Intralingual. Kesalahan yang disebabkan oleh transfer intralingual adalah kesalahan yang terjadi dalam bahasa target itu sendiri (bukan pengaruh dari bahasa lain). Kesalahan seperti itu biasanya berupa: Generalisasi berlebih. Generalisasi berlebih meliputi fakta dan kebiasaan pemelajar bahasa membentuk bentuk yang sama yang ia ketahui dalam bahasa yang sedang dipelajarinya. Pemelajar bahasa menyamaratakan semua kaidah dalam bahasa tersebut; Ketidaktahuan akan batas aturan suatu bahasa. Merupakan penerapan suatu aturan bahasa ke bagian lain yang tidak menggunakan aturan tersebut. Jenis kesalahan itu hampir sama dengan yang pertama karena masih tergolong dalam tindakan generalisasi. Perbedaannya adalah yang kedua bertolak dari ketidaktahuan sedangkan yang pertama disebabkan perasaan serba tahu menempatkan sesuatu; Penerapan kaidah secara tidak lengkap. Jika suatu saat pemelajar menerapkan kaidah secara berlebihan, pada saat yang lain pemelajar cenderung tidak lengkap menerapkan kaidah. Hal itu mungkin disebabkan sikap menghindarkan beban linguistik yang terlalu besar. 


\section{Deskripsi Data Kesalahan Penggunaan Partikel $\mathrm{Ni}$ dan $\mathrm{De}$ dalam Soal}

Berikut ini merupakan soal yang terdapat di dalam kuesioner.

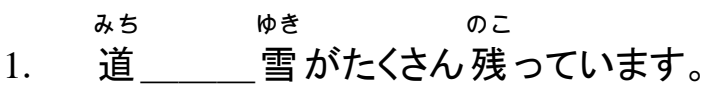

たなか たいわん う じゅうねん帆んい す

2. 田中さんは台湾_—_生まれたそうです。それから十 年ぐらい上 海——_住んでいた そうです。(台湾 : Taiwan; 上 海 : Shanghai )

きのう ちか かじ代

3. 昨日、デパートの近く_㛐事があつた。(火事 : kebakaran )

けさ わたし やまだせんせい あ

4. 今朝、私 はモール—山田先 生に会った。 かれ ところ なに

5. 彼はあんな 所 何をしているんだろう。 だいとうりょうへや ときどきかいぎーだいとうりょう

6. 大 統 領 の部屋 時 々会議がある。(大 統 領 : presiden )

じろういまきっさてん つと きっさてん つと

7. 次郎は今契茶店_—_勤めています。(喫茶店：kafe；勤める： bekerja )

みちことしょかん柿

8. 美智子は図書館——働いてみたいと思っている。

うえだ きょうと りゅうがくせいりょう りゅうがくせいりょう

9. 上田さんは、京都_—— 留 学 生 寮_—_住んでいました。（留 学 生 寮：asrama mahasiswa asing )

くるま はし ちか と くだ化

10. 車 をあの橋の近く___止めて下さい。(橋：jembatan )

かれわたしいえ と と

11. 彼は私の家 泊まってもらいます。(泊まる：menginap )

12. あなたはかさをどこ——置きましたか。（置く：meletakkan/menaruh ） しょくどう ちゅうしく ほんや じしょ か

13. 食 堂—昼 食をしてから、本屋——辞書を買いました。

にほん あくしゅ あくしゅ

14. 日本___は、握 手 はあまりいっぱんてきではありません。（握 手 : berjabat tangan; いっぱ んてき : umum )

にほん あくしゅしゅうかん市くしゅ

15. 日本__は、握 手の習 慣 はありません。( 握 手 : jabat tangan ) 
Tabel 1 Persentase dan Jenis Kesalahan Responden Mahasiswa Semester 6

\begin{tabular}{|c|c|c|c|c|c|c|c|c|}
\hline \multirow{3}{*}{ Soal No } & \multirow{3}{*}{$\begin{array}{l}\text { Jumlah Mahasiswa } \\
\text { yang menjawab } \\
\text { benar }\end{array}$} & \multirow{3}{*}{$\begin{array}{l}\text { Prosentase } \\
\quad(\%)\end{array}$} & \multirow{3}{*}{$\begin{array}{c}\text { Jumlah } \\
\text { Mahasiswa } \\
\text { yang menjawab } \\
\text { salah }\end{array}$} & \multirow{3}{*}{$\begin{array}{c}\text { Prosentase } \\
(\%)\end{array}$} & \multirow[b]{3}{*}{$\begin{array}{l}\text { Transfer } \\
\text { Interlingual }\end{array}$} & \multicolumn{2}{|c|}{ Jenis Kesalahan } & \\
\hline & & & & & & \multicolumn{3}{|c|}{ Transfer Intralingual } \\
\hline & & & & & & $\begin{array}{c}\text { Generalisasi } \\
\text { Berlebih }\end{array}$ & $\begin{array}{c}\text { Ketidakahuan akan } \\
\text { batas-batas aturan suatu } \\
\text { bahasa }\end{array}$ & $\begin{array}{c}\text { Penerapan } \\
\text { kaidah } \\
\text { secara tidak } \\
\text { lengkap }\end{array}$ \\
\hline 1 & 23 & 50 & 23 & 50 & & & + & \\
\hline $2 \mathrm{~A}$ & 26 & 57 & 20 & 43 & & & + & \\
\hline $2 \mathrm{~B}$ & 34 & 74 & 12 & 26 & & & + & \\
\hline 3 & 14 & 30 & 32 & 70 & + & + & + & + \\
\hline 4 & 38 & 83 & 8 & 17 & & + & & \\
\hline 5 & 41 & 89 & 5 & 11 & & + & & \\
\hline 6 & 19 & 41 & 27 & 59 & + & + & + & + \\
\hline 7 & 12 & 26 & 34 & 74 & + & + & + & + \\
\hline 8 & 33 & 72 & 13 & 28 & & + & + & \\
\hline $9 \mathrm{~A}$ & 35 & 76 & 11 & 24 & & + & & \\
\hline $9 \mathrm{~B}$ & 41 & 89 & 5 & 11 & & & + & \\
\hline 10 & 34 & 74 & 12 & 26 & & & + & \\
\hline 11 & 33 & 72 & 13 & 28 & & & + & \\
\hline 12 & 27 & 59 & 19 & 41 & & & + & \\
\hline $13 \mathrm{~A}$ & 38 & 83 & 8 & 17 & & & + & \\
\hline $13 \mathrm{~B}$ & 41 & 89 & 5 & 11 & & & + & \\
\hline 14 & 29 & 63 & 17 & 37 & & + & + & + \\
\hline 15 & 24 & 52 & 22 & 48 & & & + & \\
\hline Rata-Rata & 542 & 65 & 286 & 35 & 3 & 8 & 15 & 4 \\
\hline
\end{tabular}

Tabel 2 Persentase dan Jenis Kesalahan Responden Mahasiswa Semester 8

\begin{tabular}{|c|c|c|c|c|c|c|c|c|}
\hline \multirow{3}{*}{ Soal No } & \multirow{3}{*}{$\begin{array}{c}\text { Jumlah } \\
\text { Mahasiswa } \\
\text { yang } \\
\text { menjawab } \\
\text { benar }\end{array}$} & \multirow{3}{*}{$\begin{array}{c}\text { Prosentase } \\
(\%)\end{array}$} & \multirow{3}{*}{$\begin{array}{c}\text { Jumlah Mahasiswa } \\
\text { yang menjawab } \\
\text { salah }\end{array}$} & \multirow{3}{*}{$\begin{array}{c}\text { Prosentase } \\
(\%)\end{array}$} & \multicolumn{4}{|c|}{ Jenis Kesalahan } \\
\hline & & & & & \multirow[b]{2}{*}{$\begin{array}{l}\text { Transfer } \\
\text { Interlingual }\end{array}$} & \multicolumn{3}{|c|}{ Transfer Intralingual } \\
\hline & & & & & & $\begin{array}{l}\text { Generalisasi } \\
\text { Berlebih }\end{array}$ & $\begin{array}{l}\text { Ketidakahuan akan } \\
\text { batas-batas aturan } \\
\text { suatu bahasa }\end{array}$ & $\begin{array}{c}\text { Penerapan } \\
\text { kaidah secara } \\
\text { tidak lengkap }\end{array}$ \\
\hline 1 & 14 & 42 & 19 & 58 & & & + & \\
\hline $2 A$ & 15 & 45 & 18 & 55 & & & + & \\
\hline $2 \mathrm{~B}$ & 23 & 70 & 10 & 30 & & & + & \\
\hline 3 & 13 & 39 & 20 & 61 & + & + & + & + \\
\hline 4 & 24 & 73 & 9 & 27 & & + & & \\
\hline 5 & 25 & 76 & 8 & 24 & & + & & \\
\hline 6 & 17 & 52 & 16 & 48 & + & + & + & + \\
\hline 7 & 8 & 24 & 25 & 76 & + & + & + & + \\
\hline 8 & 24 & 73 & 9 & 27 & & + & + & \\
\hline $9 \mathrm{~A}$ & 20 & 61 & 13 & 39 & & + & & \\
\hline $9 \mathrm{~B}$ & 23 & 70 & 10 & 30 & & & + & \\
\hline 10 & 22 & 67 & 11 & 33 & & & + & \\
\hline 11 & 21 & 64 & 12 & 36 & & & + & \\
\hline 12 & 23 & 70 & 10 & 30 & & & + & \\
\hline $13 \mathrm{~A}$ & 24 & 73 & 9 & 27 & & & + & \\
\hline $13 \mathrm{~B}$ & 22 & 67 & 11 & 33 & & & + & \\
\hline 14 & 20 & 61 & 13 & 39 & & + & + & + \\
\hline 15 & 19 & 58 & 14 & 42 & & & + & \\
\hline Rata-Rata & 357 & 60 & 237 & 40 & 3 & 8 & 15 & 4 \\
\hline
\end{tabular}




\section{PENUTUP}

Bertitik tolak pada latar belakang penelitian, masalah penelitan dan tujuan penelitian, dan hasil analisis data kesalahan penggunaan partikel $n i$ (に) dan de (で) terhadap mahasiswa pemelajar bahasa Jepang tingkat menengah, yaitu mahasiswa semester enam dan delapan Jurusan Bahasa Jepang Fakultas Sastra Universitas Bina Nusantara Jakarta terhadap kalimat bahasa Jepang tingkat dasar, dapat disimpulkan bahwa pada umumnya sebagian besar responden, yaitu mahasiswa semester enam dan delapan sudah cukup menguasai penggunaan partikel $n i$ (に) dan de (で) yang berfungsi untuk menunjukkan tempat/keberadaan. Jenis kesalahan yang dilakukan oleh mahasiswa dapat disebabkan transfer interlingual maupun transfer intralingual. Kesalahan yang terjadi karena faktor transfer interlingual disebabkan apabila terdapat pengaruh bahasa ibu terhadap bahasa target yang dipelajari. Dari hasil penelitian jawaban mahasiswa terhadap soal yang berhubungan dengan latar belakang mereka bahwa sebagian besar dari responden penelitian menggunakan bahasa Indonesia sebagai bahasa ibu sehingga responden banyak melakukan kesalahan karena pengaruh dari bahasa Indonesa.

Kesalahan yang terjadi karena transfer intralingual, yaitu apabila kesalahan tersebut terjadi dalam bahasa target itu sendiri tanpa dipengaruhi oleh bahasa lain. Kesalahan karena transfer intralingual biasanya berupa generalisasi berlebih, ketidaktahuan akan batas aturan suatu bahasa, dan penerapan kaidah secara tidak lengkap. Dari hasil analisis, kesalahan karena generalisasi berlebih disebabkan responden terpengaruh oleh kata kerja yang ada di akhir kalimat. Selanjutnya, didapatkan bahwa kesalahan yang disebabkan oleh ketidaktahuan akan batas aturan suatu bahasa dan penerapan kaidah secara tidak lengkap karena responden kurang menguasai tata bahasa yang juga mencakup penguasaan terhadap penggunaan partikel. Salah satu faktor penyebab kurangnya penguasaan terhadap tata bahasa, yaitu karena sebagian besar responden berpendapat bahwa mata kuliah yang paling sulit adalah tata bahasa/bunpoo dan sebagian besar dari responden merasa kesulitan dalam mempelajari huruf kanji yang terdapat dalam bahasa Jepang. Hal tersebut menurunkan minat atau menjadi penghalang bagi mereka untuk mempelajari tata bahasa Jepang dengan baik. Penyebab kurangnya penguasaan terhadap partikel selain karena kurangnya penguasaan tata bahasa, yaitu karena partikel dalam bahasa Jepang memiliki jumlah yang sangat banyak beserta fungsinya yang sangat beraneka ragam dan di samping itu dalam bahasa Jepang terdapat beberapa partikel yang memiliki fungsi yang mirip sehingga membingungkan pemelajar. 


\section{DAFTAR PUSTAKA}

Alwi, H. 2003. Tata bahasa baku bahasa Indonesia. Jakarta: Balai Pustaka.

茅野、秋元. 1987. 外国人のための助詞一その教え方と覚え方. 東京: 前田部.

Herniwati. 2001. "Penggunaan kata bantu kasus (kakujoshi) bahasa Jepang dalam karangan: Analisis kesalahan berbahasa mahasiswa indonesia pemelajar bahasa jepang tingkat dasar." Tesis S2. Jakarta: Universitas Indonesia.

片側、修、敦夫. 1988. 外国人のため日本語例文問題シリーズ 7 助詞. 東京: 荒竹勉.

Kawashima, A. 1992. Particles Plus. Toukyou: Harcourt Brace Jovanovich Japan.

増岡、行則. 1987. 日本語の文法セルフマスターシリーズ 3 格助詞. 東京: 黒潮出版.

庭三庭郎. 2004. 2005 年 1 月 31 日, http://www.geocities.co.jp/niwasaburoo/. 印用する.

Parera, J.D. 1997. Metodologi pembelajaran bahasa analisis kontrastif antarbahasa analisis kesalahan berbahasa. Edisi ke-2. Jakarta: Penerbit Erlangga.

Pedoman umum ejaan bahasa Indonesia yang disempurnakan dan pedoman umum pembentukan istilah. Bandung: Penerbit Yrama Widya.

Sakri, A. 1994. Bangun kalimat bahasa Indonesia. Edisi ke-2. Bandung: Penerbit ITB.

Simanjuntak, H. 1997. Bahasa Jepang untuk pemula. Jakarta: Kesaint Blanc.

Singarimbun, M. dan S. Effendi. 1989. Metode penelitian survai. Edisi Revisi. Jakarta: LP3ES.

酒入郁子. 1991. 外国人が日本語教師によくする 1000 の質問. 東京: バベルプレス.

Sudjianto. 2000. Gramatika bahasa Jepang Modern-Seri B. Jakarta: Kesaint Blanc.

Sugihartono. 2001. Nihongo No Joshi. Bandung: Humaniora Utama Press.

Sutedi, D. 2003. Dasar-dasar linguistik Jepang. Bandung: Humaniora Utama Press.

鈴木忍. 1978. 教師用日本語教育ハンドブック 3 文法 1 . 東京: 国際交流基金. 